\title{
FAKTOR-FAKTOR YANG MEMPENGARUHI KEPUASAN BELAJAR JARAK JAUH MAHASISWA VOKASI DI MASA PANDEMI COVID-19
}

\author{
Indarti ${ }^{1)}$, Urip Wahyuningsih22), Yulistiana ${ }^{3)}$, Ratna Suhartini'), Yuhri Inang Prihatina ${ }^{5)}$ \\ 12345 Fakultas Teknik, Universitas Negeri Surabaya \\ Email Korespondensi: indarti@unesa.ac.id
}

\begin{abstract}
ABSTRAK
Pada awal tahun 2020 hampir semua negara di dunia mengalami masa pandemi COVID-19 termasuk negara kita Indonesia sehingga pembelajaran dilakukan secara secara jarak jauh dari rumah mahasiswa masing-masing. Pembelajaran jarak jauh secara daring juga dialami pada program vokasi di Fakultas Teknik, Universitas Negeri Surabaya. Kepuasan belajar mahasiswa secara jarak jauh di evaluasi untuk perbaikan program selanjutnya. Tujuan penelitian dalam era COVID ini adalah untuk menguji faktor-faktor yang diprediksi dapat mempengaruhi kepuasan belajar jarak jauh secara daring mahasiswa vokasi di masa pandemi COVID-19. Metode penelitian menggunakan kuantitatif. Survei dilakukaan untuk mengumpulkan data melalui kuesioner yang telah disusun dalam google form dan disebar melalui WAG. Pengambilan sample dilakukan secara convenience sampling pada mahasiswa program vokasi di Fakultas Teknik, Universitas Negeri Surabaya. Pada bulan Juli sampai Agustus 2020 dilakukan pengambilan data secara online, dan diperoleh 170 responden. Dalam penelitian ini data diananalisis secara kuantitatif menggunakan program SPSS. Dari sembilan faktor yang diprediksi berpengaruh terhadap kepuasan belajar jarak jauh, hanya empat faktor terbukti secara signifikan berpengaruh terhadap kepuasan belajar jarak jauh yaitu sumber belajar elektronik yang baik (good e-resourches), konten pembelajaran (learning content), manfaaat yang dirasakan (perceived usefulness) dan interaksi antara pembelajar dan dosen (learner-instructor interaction). Penelitian ini memberikan kontribusi terhadap baik terhadap pengelola pembelajaran maupun dosen.
\end{abstract}

Kata kunci: kepuasan belajar jarak jauh, mahasiswa vokasi, e-learning, pandemi COVID-19

\begin{abstract}
During the COVID-19 pandemic, distance learning is designed through e-learning by utilizing information technology in the teaching and learning process. This distance learning has different challenges with face-to-face learning, especially with a very short preparation. The purpose of this study was to examine the factors that are predicted to affect distance learning satisfaction among vocational students during the COVID-19 pandemic. The research method uses quantitative. The survey was conducted to collect data through a questionnaire compiled on google form and distributed via WAG. Convenience sampling was carried out on vocational program students at the Faculty of Engineering, Universitas Negeri Surabaya. Data were collected from July to August 2020 and obtained 170 respondents. In this study, the data were analyzed quantitatively using the SPSS program. Nine factors have been predicted to affect distance learning satisfaction. Still, only four factors have been shown to significantly influence distance learning satisfaction: good e-resources, learning content, perceived usefulness and learner-instructor interaction. This research contributes to both the learning manager and the lecturers.
\end{abstract}

Keywords : distance learning satisvaction, vocational students, e-learning, COVID-19 pandemic

\section{PENDAHULUAN}

Organisasi Kesehatan Dunia (WHO) pada tanggal 11 Maret 2020, telah mengumumkan situasi COVID-19 sebagai pandemic yang tingkat penyebaran dan keparahannya yang mengkhawatirkan [1]. Negara kita Indonesia, termasuk yang terkena imbas dari wabah virus corona, sehingga pemerintah 
melakukan beberapa pencegahan penularan. Salah satunya adalah menghentikan kegiatan belajar di sekolah dan menggantinya dengan belajar di rumah. Perguruan tinggi juga menghentikan kegiatan belajar mengajar secara tatap muka, dan menggantinya dengan metode jarak jauh atau online. Pembelajaran jarak untuk memenuhi hak mahasiswa di perguruan tinggi untuk tetap belajar dari rumah masing-masing. Pembelajaran jarak jauh dilakukan melalui pemanfaatan teknologi dan internet. Saat ini ditengah pandemic mau tidak mau semua kelas beralih ke pembelajaran jarak jauh dengan segala kondisi dan keterbatasannya, baik dari segi pengajar maupun mahasiswa.

Di tengah masa pandemi ini pembelajaran jarak jauh di desain melalui e-learning dengan memanfaatkan IT dalam proses belajar mengajar yang dilakukan baik di sekolah maupun di PT. Pembelajaran jarak jauh ini memiliki tantangan tersendiri baik bagi pengajar maupun peserta didik karena berbeda jauh dari pembelajaran tatap muka, apalagi dengan persiapan yang sangat singkat. Namun perkembangan teknologi saat ini sangat menunjang pelaksanaan proses pembelajaran meskipun dilaksanakan dari jarak jauh. Pembelajaran jarak jauh adalah kesempatan untuk menjelajahi tempat di dunia yang lebih luas dengan berbagai budaya dan ideologi [2]. Ketika siswa beralih dari pembelajaran tradisional ke lingkungan belajar online, mereka ditantang oleh berbagai metode pembelajaran dan interaksi. Jika siswa dapat mengadopsi pendekatan e-learning yang efektif dan efisien, maka mereka dapat meningkatkan pencapaian belajar [3]. Pembelajaran online ini sangat menantang baik bagi pengajar maupun mahasiswa, apalagi bagi program vokasi yang berbasis praktek. Peserta didik merupakan key stakeholder di dalam semua tipe pembelajaran, oleh karena itu penelitian ini meneliti tentang kepuasan belajar mahasiswa.

Telah banyak peneliti yang mengevaluasi sistem e-learning, terutama tentang kepuasan belajar. Horzum (2015) meneliti hubungan interaction, stucture, social presence, dan satisfaction di Ankara University, Turkey [4]. Jafari Navimipour and B. Zareie (2015) mengusulkan variabel teknologi, konten pendidikan, motifasi dan sikap merupakan cara untuk meningkatkan kepuasan belajar karyawan di Iran melalui sistem e-learning [5]. Elkaseh dkk (2016) menekankan kemudahan penggunaan yang dirasakan peserta didik dan manfaat yang dirasakan, bersama dengan niat perilaku untuk menggunakan teknologi baru merupakan faktor-faktor penggunaan media jejaring sosial untuk elearning di pendidikan tinggi Libya [6]. Kurucay dan Inan (2017) menyelidiki efek interaksi pelajarpelajar, prestasi dan kepuasan siswa dalam pembelajaran online di Southwest University in the United States [7]. Namun, penelitian-penelitian tersebut hanya menguji berbagai faktor saja, dalam penelitian ini kami menguji banyak (sembilan) faktor yang diprediksi mempengaruhi kepuasan belajar jarak jauh dan learning outcome di Indonesia yang terdapak COVID-19 sehingga pembelajaran di lakukan secara online dengan segala kondisi dan keterbatasannya. Tujuan penelitian ini adalah untuk menguji fakor-faktor yang diprediksi mempengaruhi kepuasan belajar jarak jauh mahasiswa vokasi di masa pandemi COVID-19.

\section{A. Kepuasan Belajar}

Kepuasan belajar merupakan penilaian positif keseluruhan siswa atas pengalaman belajarnya yang diukur setelah kegiatan pembelajaran [8]. Kepuasan siswa atau peserta didik dapat didefinisikan sebagai persepsi yang berkaitan baik dalam pengalaman maupun nilai yang dirasakan dari sebuah program pendidikan yang diterima di sebuah lembaga pendidikan [9]. Kepuasan mempengaruhi tingkat motivasi mahasiswa. Survei akhir yang diberikan kepada peserta didik jarak jauh akan didapat informasi kepuasan siswa yang berharga yang dapat digunakan untuk meningkatkan suatu program pendidikan. Kepuasan belajar ditekankan sebagai salah satu yang paling faktor penting yang menentukan kualitas pembelajaran online [4]. Kepuasan belajar online dapat didefinisikan sebagai pemenuhan dan tingkat kesenangan siswa tentang berbagai aspek pembelajaran dan layanan yang mereka terima dalam pembelajaran online program. Dari aspek ini, kepuasan adalah faktor yang dapat secara langsung dipengaruhi oleh komponen layanan pembelajaran. Literatur terkait tentang kepuasan menunjukkan hal itu ada berbagai macam faktor yang mempengaruhi kepuasan dalam lingkungan belajar online. Kepuasan pelajar berkorelasi positif dengan kualitas hasil belajar [10].

\section{B. Framework dan Hipotesis}

Fokus penelitian kami disini adalah untuk menguji faktor-faktor yang diprediksi mempengaruhi kepuasan belajar mahasiswa. Faktor-faktor yang mempengaruhi kepuasan belajar mahasiswa dengan pembelajaran online dengan konteks tertentu dapat digunakan sebagai masukan untuk desain lingkungan belajar yang tepat, dan untuk penyediaan dukungan yang ditargetkan kepada mahasiswa, dengan tujuan untuk mempengaruhi pengalaman belajar online mahasiswa secara positif. Dalam 
penelitian ini kami menjabarkan ada 10 faktor yang diprediksi mempengaruhi kepuasan belajar, yaitu: pengajaran online yang baik (good e-teaching), sumber belajar online yang baik (good e-resources), penilaian (assessment), konten pembelajaran (learning content), fleksibel (perceived flexibility), manfaat yang dirasakan (percived usefulness), interaksi antar mahasiswa (learner-learner interactions), interaksi dosen dan mahasiswa (learner-instructor interactions), dan pembelajaran mandiri (self-regulated learning). Kerangka berfikir (reseach framework) dalam penelitian ini terdapat pada Gambar 1, yaitu sembilan faktor yang diuji, yang diprediksi mempengaruhi kepuasan belajar jarak jauh mahasiswa.

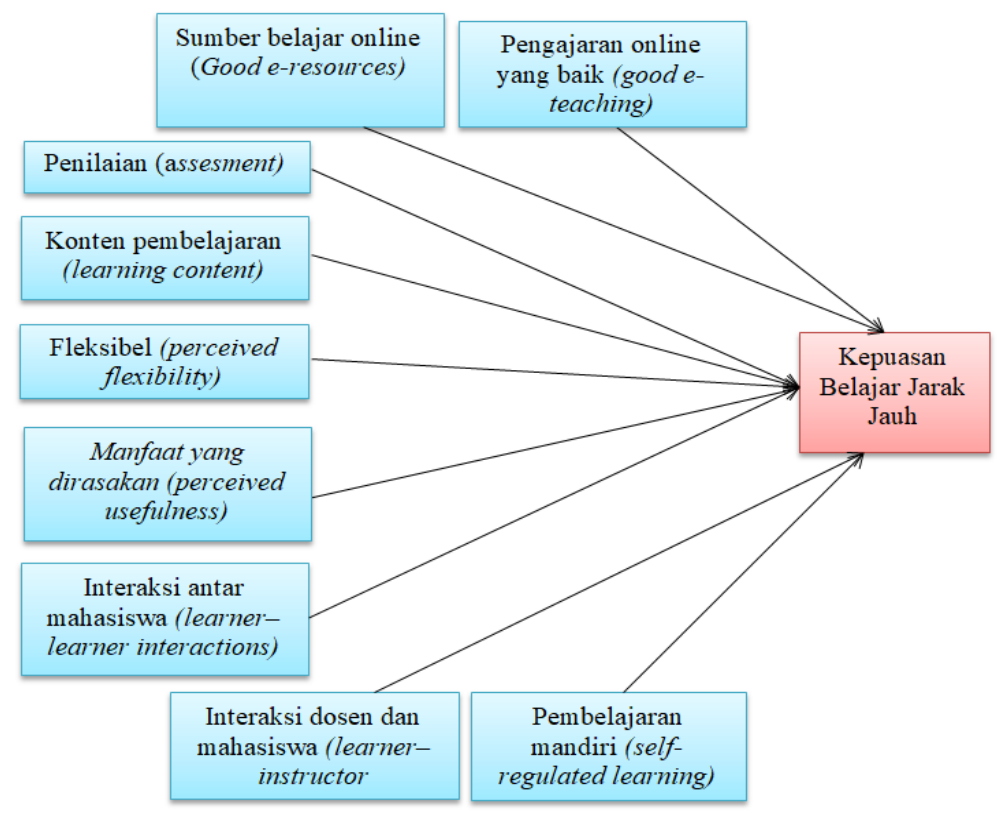

Gambar 1. Reasearch Framework

Pendekatan pengajaran di pendidikan tinggi, disebutkan beberapa pengajaran yang baik antara lain: pertama, memahami bahwa tujuan mendasar pengajaran adalah memperoleh pengetahuan dan mendapatkan kecerdasan; kedua, peran instruktur sebagai pengasuh siswa; ketiga, model reflektif dan adaptif sehingga instruktur dapat beradaptasi dengan situasi pengajaran apapun dan keempat adalah instruktur sebagai model moral yang percaya pada kebenaran dan jujur [11]. Untuk mengukur skala pengajaran yang baik antara lain staff pengajar memberikan umpan balik, memotivasi siswa, membuat upaya nyata untuk memahami kesulitan belajar mahasiswa, mampu menjelaskan, berupaya untuk membuat mata kuliah menarik, dan meluangkan waktu untuk mengomentari pekerjaan mahasiswa [12]. Keahlian mengajar merupakan factor yang paling berpengaruh dalam kepuasan siswa di perguruan tinggi [13]. Hipotesis yang kami ajukan adalah:

\section{H1: good e-teaching berpengaruh terhadap kepuasan belajar jarak jauh.}

Good e-Resources mengukur persepsi mahasiswa tentang sejauh mana materi dan aktivitas online membantu pembelajaran [12]. Defininis e-resources atau sumberdaya elekronik adalah materi yang dapat diakses dalam format elektronik [14]. E-resources memberikan kesempatan kepada siswa untuk mengakses, mengevaluasi, dan mengatur informasi yang ada dari semua sumber yang ada dalam masyarakat saat ini [15]. Studi terbaru menunjukkan bahwa pengguna lebih memilih eresources daripada cetak karena publikasi dan pengiriman diambil secara instan [14]. Beberapa penelitian telah menguji efektifitas sumber belajar elektronik terhadap pembelajaran. Sumber daya elektronik memberikan memberikan pada mahasiswa baik untuk pembelajaran maupun penelitian [16]. Ayrat dkk menyatakan kesuksesan penggunaan media elektronik dalam lingkungan e-learning [17]. Sehingga kami merumuskan hipotesis sebagai berikut:

H2: good e-resources berpengaruh terhadap kepuasan belajar jarak jauh 
Tipe penilaian yang tepat sangat menentukan keberhasilan mengakses informasi terkait dengan proses pembelajaran [18]. Sedangkan penilaian yang berpusat pada pembelajaran cenderung mengadopsi strategi penilaian yang lebih fleksibel dimana siswa sering diberikan pilihan yang sesuai dengan minat atau kebutuhan mereka. Siswa menganggap penilaian adalah yang paling penting dalam dimensi pengajaran [19]. Materi interaktif berpengaruh signifikan terhadap hubungan antara motivasi untuk penilaian yang lebih baik dan kepuasan belajar, serta hubungan antara motivasi internal dan kepuasan belajar [20]. Manajemen penilaian berhubungan positif dengan kinerja tinggi peserta didik [21]. Untuk itu hipotesis ke-empat yang kami rumuskan adalah:

\section{H3: assessmnet berpengaruh terhadap kepuasan belajar jarak jauh}

Konten pembelajaran online mengacu pada program pembelajaran, desain pembelajaran online serupa dengan format kelas dalam hal deskripsi, tujuan, ruang lingkup dan evaluasi [22]. Konten pendidikan, motivasi, dan sikap secara signifikan mempengaruhi kepuasan belajar karyawan [5]. Siswa lebih terlibat dengan konten kursus dan menunjukkan tingkat pemahaman dan penguasaan topik yang lebih tinggi [23]. Konten e-learning yang dirancang dengan baik dapat memfasilitasi pembelajaran online dan meningkatkan motivasi untuk menggunakan preabgkat e-learning. Jadi kami mengusulkan hipotesis sebagai berikut:

\section{H4: learning content berpengaruh terhadap kepuasan belajar jarak jauh}

Pembelajaran jarak jauh memiliki fleksibilitas dalam hal waktu, lokasi dan metode. Penghapusan hambatan fisik memungkinkan interaksi yang lebih dinamis yang mendorong pembentukan pembelajaran konstruktif dan peluang untuk pembelajaran, dengan tidak adanya batasan waktu dan ruang dalam e-Learning, siswa dapat berkomunikasi secara instan, kapanpun, dimanapun [25]. Definisi fleksibilitas kursus e-Learning adalah persepsi peserta didik tentang efisiensi dan efek dari penerapan e-Learning dalam jam kerja, pembelajaran, dan perjalanan mereka. Karena itu, hipotesis ini adalah:

\section{H5: perceived flexibiliy berpengaruh terhadap kepuasan belajar jarak jauh}

Perceived usefulness atau manfaat yang dirasakan mahasiswa adalah sejauh mana mahasiswa percaya bahwa sesuatu akan meningkatkan kinerja pekerjaannya [26]. Kegunaan atau manfaat yang dirasakan merupakan indikator motivasi ekstrinsik seseorang untuk menggunakan teknologi [24]. Kegunaan yang dirasakan memuat item tentang peningkatan efektifitas belajar, peningkatan kinerja, manfaat untuk masa depan, dan peningkatan produktifitas [27]. Perceived usefulness atau manfaat penggunaan dari media sosial dianggap sebagai faktor kunci dalam menilai niat perilaku siswa dan guru dalam menerima dan menggunakan pembelajaran daring di pendidikan tinggi Libya [6]. Oleh karena itu:

\section{H6: perceived usefulness berpengaruh terhadap kepuasan belajar jarak jauh}

Interaktivitas didefinisikan sebagai kegiatan atau aksi antar individu/siswa atau aktivitas antar siswa dan computer/program [28]. Interaksi siswa dan instruktur merupakan salah satu predictor yang baik bagi kepuasan belajar [29]. Interaktivitas adalah factor lain yang mempengaruhi pembelajaran online [4]. Menurut Bolliger (2004) pembelajar jarak jauh dapat mengalami perasaan terisolasi, dan tingkat frustrasi dan kecemasan tinggi jika komunikasi dan interaksi yang kurang antara berbagai pihak. Instruktur harus memfasilitasi semua jenis interaktivitas dalam kursus pembelajaran jarak jauh yang sesuai. Interaksi pembelajar-pembelajar adalah komunikasi timbal balik dua arah antara siswa yang bertukar informasi, pengetahuan, pemikiran dan ide [8]. Lingkungan belajar dimana interaksi social dan kolaborasi diperbolehkan dan didorong, mengarah pada hasil pembelajaran yang positif. Sehingga hipotesis:

H7: learner-learner interaction berpengaruh terhadap kepuasan belajar jarak jauh

H8: learner-instructor interaction berpengaruh terhadap kepuasan belajar jarak jauh

Self-regulated learning atau regulasi diri mengacu pada berbagai strategi yang digunakan oleh peserta didik untuk menyadari dan mengendalikan pemikiran mental, termasuk memahami proses kognitif mereka, mempelajari gaya belajar mereka, menyadari bias kognitif mereka, dan menentukan 
masalah yang paling efektif- strategi pemecahan [30]. Dalam konteks e-learning, regulasi diri metakognitif dalam kursus online terbukti berkorelasi positif dengan keterlibatan kognitif dan emosional mereka [31]. Strategi dan prestasi akademik dalam lingkungan pembelajaran pendidikan tinggi online mengungkapkan bahwa strategi manajemen waktu, metakognisi, regulasi upaya, dan berpikir kritis berkorelasi positif dengan hasil akademik, tetapi ada sedikit dukungan empiris untuk dampak positif dari latihan, elaborasi, dan organisasi [32]. Karena itu kami kami berhipotesis:

\section{H9: self-regulated learning berpengaruh terhadap kepuasan belajar jarak jauh}

\section{METODE}

Kami melakukan penelitian survei untuk mengumpulkan data melalui kuesioner yang telah disusun dalam google form dan disebar melalui WAG. Pengambilan sample dilakukan secara convenience sampling pada mahasiswa program vokasi di Fakultas Teknik, Universitas Negeri Surabaya. Pada bulan Juli sampai Agustus 2020, telah dilakukan pengambilan data secara online. Dalam penelitian ini data diananalisis secara kuantitatif menggunakan program SPSS.

\section{A. Profil Responden}

Penyebaran kuesioner yng telah dilakukan secara online selama 2 bulan dan didapatkan jumlah responden yaitu 170 mahasiswa vokasi di Fakultas Teknik, Universitas Negeri Surabaya yang profilnya digambarkan pada Tabel 1. Responden terdiri dari delapan program studi yaitu D4 Teknik Mesin 2019 (1\%), D4 Teknik Listrik 2019 (9,4\%), D4 Teknik Transportasi 2019 (10\%), D4 Teknik Sipil 2019 (11,2\%), D4 Teknik Informatika $2019(11,2 \%)$, D4 Tata Boga $2019(19,4 \%)$, D4 Tata Busana 2019 (15,2\%) dan D3 Tata Busana 2018 (16,4\%). Responden kebanyakan adalah wanita (65,2\%) dengan gaji orang tua paling banyak $3-5$ juta perbulan $(44,7 \%)$, di bawah 3 juta $(37,6 \%), 7,6-10$ juta $(4,1 \%)$ dan di atas 10 juta (1\%). Pada masa pandemi mahasiswa belajar dari rumah masingmasing yang jaringan internetnya beragam, yaitu kadang-kadang jaringan sulit (57\%), lancar $40 \%$ dan sulit/ kurang lancar hanya 2,9\%. Cara memperoleh jaringan internet kebanyakan menggunakan paket data $(64 \%)$ dan sisanya langganan wifi.

Tabel 1. Demografis Responden

\begin{tabular}{llcc}
\hline & Variables & Frequency & $\%$ \\
\hline Program Studi & D4 Teknik Mesin 2019 & 2 & 1 \\
& D4 Teknik Listrik 2019 & 16 & 9,4 \\
& D4 Transportasi 2019 & 17 & 10 \\
& D4 Teknik Sipil 2019 & 19 & 11,2 \\
& D4 Informatika 2019 & 19 & 11,2 \\
& D4 Tata Boga 2019 & 33 & 19,4 \\
& D4 Tata Busana 2019 & 26 & 15,2 \\
& D3 Tata Busana 2018 & 28 & 16,4 \\
\hline Jenis Kelamin & Pria & 59 & 34,7 \\
& Wanita & 111 & 65,2 \\
\hline Gaji orang tua tiap bulan & Dibawah 3 juta & 64 & 37,6 \\
& 3 - 5 juta & 76 & 44,7 \\
& 5 - 7,5 juta & 21 & 12,3 \\
& $7,6-10$ juta & 7 & 4,1 \\
& Diatas 10 juta & 2 & 1 \\
\hline Jaringan internet & Sulit/ kurang lancar & 5 & 2,9 \\
& Kadang-kadang sulit & 97 & 57 \\
& Lancar & 68 & 40 \\
\hline Cara memperoleh & jaringan & 109 & 64 \\
internet & Paket data & 61 & 36 \\
\hline
\end{tabular}




\section{B. Instrumen}

Instrumen penelitian berupa kuesioner faktor-faktor yang diprediksi berpengaruh terhadap kepuasan belajar jarak jauh mahasiswa vokasi Universitas Negeri Surabaya dalam masa pandemic COVID-19. Selain itu instrumen juga memuat data demografi responden. Multi item scale digunakan untuk mengukur variable yang diprediksi berpengaruh terhadap kepuasan belajar jarak jauh, menggunakan 5 poin skala Likert. Dimulai dari nilai 1 untuk pernyataan sangat tidak setuju, sampai nilai 5 untuk pernyataan sangat setuju. Instrumen kuesioner menggunakan instrumen dalam 10 variabel yang telah digunakan peneliti sebelumnya. Skala pengukuran pengajaran online yang baik (good e-teaching) dan sumber belajar online yang baik (good e-resourches) mengadopsi penelitian Ginns \& Ellis (2007) yang terdiri dari tujuh dan lima butir kuesioner [33]. Skala pengukuran penilaian/ assessment menggunakan tiga butir [25]. Instrumen yang telah digunakan oleh Kuo dkk. (2014) telah di adopsi dalam penelitian ini untuk skala pengukuran konten pembelajaran (4 butir) dan interaksi antar mahasiswa (8 butir) dan 3 butir skala pengukuran kepuasan belajar [29]. Instrumen diadopsi dari Arbaugh (2000) yaitu untuk skala pengukuran interaksi dengan dosen (learner-instructor interactions), fleksibilitas (perceived flexibility), dan manfaat yang diterima (perceived flexibility) [27]. Kemandirian belajar (self-regulated learning) juga mengadopsi instrumen yang telah dilakukan peneliti sebelumnya [30], sehingga total instrumen adalah 54 butir atau items.

\section{Validitas dan Reliabilitas}

Data yang diperoleh kemudian diperiksa untuk menentukan apakah memenuhi syarat uji selanjutnya melalui uji reliabilitas (cronbach's alpha) dan uji validitas yang didokumenkan pada Tabel 2. SPSS digunakan untuk mendapatkan koefisien reliabilitas. Hasil uji Cronbach's alpha antara 0,798 untuk assesment - 0,906 untuk satisfaction. Nilai alpha lebih besar dari 0,70 dianggap signifikan secara statistik. Validitas konvergen dinilai berdasarkan kriteria estimasi koefisien indikator siginifikan pada posisinya faktor konstruksi yang mendasari dan melebihi 0,5.

Tabel 2. Hasil Uji Validitas dan Reliablilitas Instrumen

\begin{tabular}{|c|c|c|c|c|c|c|c|}
\hline Variables & Items & $\begin{array}{c}r \\
\text { hitung }\end{array}$ & $r$ tabel & Kesimpulan & $\begin{array}{c}\text { Alpha } \\
\text { cronbach's }\end{array}$ & Kriteria & Kesimpulan \\
\hline \multirow{7}{*}{$\begin{array}{l}\text { Good e- } \\
\text { teaching } \\
\text { (X1) }\end{array}$} & $\mathrm{X} 1.1$ & 0,779 & 0,151 & Valid & \multirow{7}{*}{0,836} & 0,60 & \multirow{7}{*}{ Reliabel } \\
\hline & X1.2 & 0,790 & 0,151 & Valid & & 0,60 & \\
\hline & $\mathrm{X} 1.3$ & 0,798 & 0,151 & Valid & & 0,60 & \\
\hline & X1.4 & 0,807 & 0,151 & Valid & & 0,60 & \\
\hline & X1.5 & 0,760 & 0,151 & Valid & & 0,60 & \\
\hline & X1.6 & 0,304 & 0,151 & Valid & & 0,60 & \\
\hline & X1.7 & 0,804 & 0,151 & Valid & & 0,60 & \\
\hline \multirow{5}{*}{$\begin{array}{l}\text { Good e- } \\
\text { resources } \\
(\mathrm{X} 2)\end{array}$} & $\mathrm{X} 2.1$ & 0,787 & 0,151 & Valid & \multirow{5}{*}{0,826} & 0,60 & \multirow{5}{*}{ Reliabel } \\
\hline & X2.2 & 0,836 & 0,151 & Valid & & 0,60 & \\
\hline & X2.3 & 0,798 & 0,151 & Valid & & 0,60 & \\
\hline & X2.4 & 0,705 & 0,151 & Valid & & 0,60 & \\
\hline & X2.5 & 0,713 & 0,151 & Valid & & 0,60 & \\
\hline \multirow{3}{*}{$\begin{array}{l}\text { Assesment } \\
\text { (X3) }\end{array}$} & X3.1 & 0,829 & 0,151 & Valid & \multirow{3}{*}{0,798} & 0,60 & \multirow{3}{*}{ Reliabel } \\
\hline & X3.2 & 0,876 & 0,151 & Valid & & 0,60 & \\
\hline & X3.3 & 0,826 & 0,151 & Valid & & 0,60 & \\
\hline \multirow{4}{*}{$\begin{array}{l}\text { Learning } \\
\text { content (X4) }\end{array}$} & $\times 5.1$ & 0,804 & 0,151 & Valid & \multirow{4}{*}{0,813} & 0,60 & \multirow{4}{*}{ Reliabel } \\
\hline & X4.2 & 0,834 & 0,151 & Valid & & 0,60 & \\
\hline & $\times 4.3$ & 0,803 & 0,151 & Valid & & 0,60 & \\
\hline & $X 4.4$ & 0,761 & 0,151 & Valid & & 0,60 & \\
\hline \multirow{8}{*}{$\begin{array}{l}\text { Perceived } \\
\text { flexibility } \\
\text { (X5) }\end{array}$} & X5.1 & 0,677 & 0,151 & Valid & \multirow{8}{*}{0,848} & 0,60 & \multirow{8}{*}{ Reliabel } \\
\hline & X5.2 & 0,713 & 0,151 & Valid & & 0,60 & \\
\hline & X5.3 & 0,564 & 0,151 & Valid & & 0,60 & \\
\hline & X5.4 & 0,729 & 0,151 & Valid & & 0,60 & \\
\hline & $\times 5.5$ & 0,791 & 0,151 & Valid & & 0,60 & \\
\hline & X5.6 & 0,701 & 0,151 & Valid & & 0,60 & \\
\hline & X5.7 & 0,713 & 0,151 & Valid & & 0,60 & \\
\hline & X5.8 & 0,685 & 0,151 & Valid & & 0,60 & \\
\hline
\end{tabular}




\begin{tabular}{|c|c|c|c|c|c|c|c|}
\hline Variables & Items & $\begin{array}{c}r \\
\text { hitung }\end{array}$ & $r$ tabel & Kesimpulan & $\begin{array}{c}\text { Alpha } \\
\text { cronbach's }\end{array}$ & Kriteria & Kesimpulan \\
\hline \multirow{4}{*}{$\begin{array}{l}\text { Perceived } \\
\text { usefulness } \\
\quad(X 6)\end{array}$} & X6.1 & 0,924 & 0,151 & Valid & \multirow{4}{*}{0,899} & 0,60 & \multirow{4}{*}{ Reliabel } \\
\hline & X6.2 & 0,890 & 0,151 & Valid & & 0,60 & \\
\hline & $\times 6.3$ & 0,812 & 0,151 & Valid & & 0,60 & \\
\hline & $\times 6.4$ & 0,879 & 0,151 & Valid & & 0,60 & \\
\hline \multirow{8}{*}{$\begin{array}{l}\text { Learner- } \\
\text { learner } \\
\text { interactions } \\
\quad(\mathrm{X} 7)\end{array}$} & X7.1 & 0,642 & 0,151 & Valid & \multirow{8}{*}{0,886} & 0,60 & \multirow{8}{*}{ Reliabel } \\
\hline & X7.2 & 0,779 & 0,151 & Valid & & 0,60 & \\
\hline & X7.3 & 0,745 & 0,151 & Valid & & 0,60 & \\
\hline & $\times 7.4$ & 0,786 & 0,151 & Valid & & 0,60 & \\
\hline & X7.5 & 0,814 & 0,151 & Valid & & 0,60 & \\
\hline & X7.6 & 0,755 & 0,151 & Valid & & 0,60 & \\
\hline & $\times 7.7$ & 0,763 & 0,151 & Valid & & 0,60 & \\
\hline & X7.8 & 0,715 & 0,151 & Valid & & 0,60 & \\
\hline \multirow{6}{*}{$\begin{array}{l}\text { Learner- } \\
\text { instructor } \\
\text { interactions } \\
\text { (X8) }\end{array}$} & X8.1 & 0,796 & 0,151 & Valid & \multirow{6}{*}{0,869} & 0,60 & \multirow{6}{*}{ Reliabel } \\
\hline & X8.2 & 0,832 & 0,151 & Valid & & 0,60 & \\
\hline & X8.3 & 0,825 & 0,151 & Valid & & 0,60 & \\
\hline & $X 8.4$ & 0,783 & 0,151 & Valid & & 0,60 & \\
\hline & X8.5 & 0,556 & 0,151 & Valid & & 0,60 & \\
\hline & X8.6 & 0,850 & 0,151 & Valid & & 0,60 & \\
\hline \multirow{4}{*}{$\begin{array}{l}\text { Self- } \\
\text { regulated } \\
\text { learning } \\
(\mathrm{X9})\end{array}$} & X9.1 & 0,763 & 0,151 & Valid & \multirow{4}{*}{0,845} & 0,60 & \multirow{4}{*}{ Reliabel } \\
\hline & X9.2 & 0.847 & 0.151 & Valid & & 0.60 & \\
\hline & $\times 9.3$ & 0,864 & 0,151 & Valid & & 0,60 & \\
\hline & $\times 9.4$ & 0,829 & 0,151 & Valid & & 0,60 & \\
\hline \multirow{5}{*}{$\begin{array}{l}\text { Satisfaction } \\
(\mathrm{Y})\end{array}$} & Y.1 & 0,854 & 0,151 & Valid & \multirow{5}{*}{0,906} & 0,60 & \multirow{5}{*}{ Reliabel } \\
\hline & Y.2 & 0,889 & 0,151 & Valid & & 0,60 & \\
\hline & Y.3 & 0,869 & 0,151 & Valid & & 0,60 & \\
\hline & Y.4 & 0,805 & 0,151 & Valid & & 0,60 & \\
\hline & Y.5 & 0,850 & 0,151 & Valid & & 0,60 & \\
\hline
\end{tabular}

\section{HASIL DAN PEMBAHASAN}

\section{A. Deskriptif Statistik}

Dari hasil deskriptif statistik yang tampak pada Tabel 3, semua nilai mean lebih dari 3 yang artinya baik. Mean tertinggi adalah self-regulated learning $(3,801)$, kemudian interaksi antar mahasiswa $(3,718)$, dan interaksi dosen dan mahasiswa $(3,546)$.

Tabel 3. Deskriptif Statistik

\begin{tabular}{clcc}
\hline No. & \multicolumn{1}{c}{ Variables } & M & SD \\
\hline 1 & Good e-teaching & 3,479 & 0,910 \\
2 & Good e-resource & 3,359 & 0,946 \\
3 & Assesment & 3,520 & 0,847 \\
4 & Learning content & 3,365 & 0,937 \\
5 & Perceived flexibility & 3,328 & 1,000 \\
6 & Perceived usefulness & 3,159 & 0,955 \\
7 & Learner-learner interactions & 3,718 & 0,879 \\
8 & Learner-instructor interactions & 3,546 & 0,893 \\
9 & Self-regulated learning & 3,801 & 0,783 \\
10 & Satisfaction & 3,049 & 1,048 \\
\hline
\end{tabular}

\section{B. Uji Hipotesis}

Uji hipotesis telah dilakukan menggunakan program SPSS dan diperoleh hasil pada Tabel 4. Terdapat empat hipotesis yang diterima diantara 9 hipotesis yang diprediksi berpengaruh terhadap variabel dependent. Hipotesis atau $\mathrm{H} 2$, hipotesis atau $\mathrm{H} 4$, hipotesis atau $\mathrm{H} 6$ dan hipotesis atau $\mathrm{H} 8$ dinyatakan diterima, sedangkan hipotesis atau $\mathrm{H} 1$, hipotesis atau $\mathrm{H} 3$, hipotesis atau $\mathrm{H} 5$, hipotesis 
atau $\mathrm{H} 7$, dan hipotesis atau $\mathrm{H} 9$ ditolak. $\mathrm{H} 2$ memiliki nilai $p=0,021$, good e-resources berpengaruh terhadap kepuasan belajar mahasiswa. $\mathrm{H} 4$ dengan nilai $p=0,002$, learning content berpengaruh terhadapa kepuasan belajar mahasiswa. H6 memiliki nilai $p=0,000$ dan $\mathrm{H} 8$ memiliki nilai $p=0,018$. Perceived usefulness (manfaat) dan interaksi dosen dan mahasiswa berpengaruh secara signifikan terhadap kepuasan belajar mahasiswa.

Tabel 4. Hasil Uji Hipotesis

\begin{tabular}{|c|c|c|c|c|c|c|}
\hline $\mathbf{H}$ & Hypothesized path & Estimate & $\begin{array}{c}\text { Standard } \\
\text { error }\end{array}$ & T value & $P$ value & Results \\
\hline $\mathrm{H} 1$ & $\begin{array}{l}\text { good e-teaching ---- } \\
\text { satisfaction }\end{array}$ & $-0,036$ & 0,072 & $-0,504$ & 0,615 & ditolak. \\
\hline $\mathrm{H} 2$ & $\begin{array}{l}\text { good e-resources ---- } \\
\text { satisfaction }\end{array}$ & 0,184 & 0,097 & 2,336 & 0,021 & diterima. \\
\hline H3 & $\begin{array}{l}\text { assesment ---- } \\
\text { satisfaction }\end{array}$ & $-0,010$ & 0,146 & $-0,136$ & 0,892 & ditolak. \\
\hline $\mathrm{H} 4$ & $\begin{array}{l}\text { learning content ---- } \\
\text { satisfaction }\end{array}$ & 0,227 & 0,108 & 3,152 & 0,002 & diterima. \\
\hline $\mathrm{H} 5$ & $\begin{array}{l}\text { perceived flexibility ---- } \\
\text { satisfaction }\end{array}$ & 0,085 & 0,067 & 1,084 & 0,280 & ditolak. \\
\hline $\mathrm{H} 6$ & $\begin{array}{l}\text { perceived usefulness ---- } \\
\text { satisfaction }\end{array}$ & 0,416 & 0,101 & 5,586 & 0,000 & diterima. \\
\hline $\mathrm{H} 7$ & $\begin{array}{l}\text { learner-learner } \\
\text { interactions ---- } \\
\text { satisfaction }\end{array}$ & $-0,069$ & 0,059 & $-1,037$ & 0,301 & ditolak. \\
\hline $\mathrm{H} 8$ & $\begin{array}{l}\text { learner-instructor } \\
\text { interactions ---- } \\
\text { satisfaction }\end{array}$ & 0,179 & 0,084 & 2,394 & 0,018 & diterima. \\
\hline $\mathrm{H} 9$ & $\begin{array}{l}\text { self-regulated learning ---- } \\
\text { satisfaction }\end{array}$ & $-0,093$ & 0,106 & $-1,513$ & 0,132 & ditolak. \\
\hline
\end{tabular}

\section{Diskusi/ Pembahasan}

Seperti yang telah dikemukakan sebelumnya, tujuan penelitian kami adalah untuk menguji fakor-faktor yang diprediksi mempengaruhi kepuasan belajar jarak jauh mahasiswa vokasi di masa pandemi COVID-19. Dari sembilan faktor yang diprediksi berpengaruh terhadap kepuasan belajar jarak jauh, hanya empat faktor terbukti secara signifikan berpengaruh terhadap kepuasan belajar yaitu sumber belajar elektronik yang baik (good e-resourches), konten pembelajaran (learning content), manfaaat yang dirasakan (perceived usefulness) dan interaksi dosen dan mahasiswa (learnerinstructor interaction).

Good e-Resources mengukur persepsi mahasiswa tentang sejauh mana materi dan aktivitas online membantu pembelajaran. Good e-resources berpengaruh terhadap kepuasan belajar jarak jauh. Hasil penujian SPSS ditemukan $P$-value adalah $0,021(<0,05)$ yang artinya hipotesis diterima. Materi pembelajaran di program vokasi Fakultas Teknik Universitas Negeri Surabaya telah dirancang sehingga menarik bagi mahasiswa, bahan ajar online sangat membantu pada masa pandemi yang tiba-tiba, materi online telah membantu mahasiswa belajar secara mandiri untuk menggantikan kegiatan tatp muka. Penelitian ini menguatkan penelitian sebelumnya bahwa good e-resources sebagai salah satu pengalaman siswa dalam e-learning, dan hasilnya terdapat korelasi yang baik antara good e-resources dan e-learning [33], penelitian Varghese, M. Faith, and M. Jacob (2012) bahwa sumber daya elektronik memberikan dampak positif pada berbagai aspek pembelajaran di bidang biokimia [34]. E-resources memberikan dampak kepuasan siswa terhadap pembelajaran berbasis web [35] dan kesuksesan penggunaan media elektronik dalam lingkungan e-learning [17].

Learning content mengacu pada program pembelajaran, desain pembelajaran online serupa dengan format kelas dalam hal deskripsi, tujuan, ruang lingkup dan evaluasi. Learning content berpengaruh terhadap kepuasan belajar jarak jauh. Hasil penujian SPSS ditemukan $P$-value adalah $0,002(<0,05)$ yang artinya hipotesis diterima. Materi kuliah selama pembelajaran online membantu mahasiswa memahami konten pembelajaran dengan baik, dapat merangsang minat belajar mahasiswa, dapat menghubungkan pengalaman pribadi dengan konsep atau pengetahuan baru, dan mudah diakses oleh mahasiswa. Hasil penelitian kami mendukung beberapa penelitian sebelumnya 
yang dilakukan oleh N. Jafari Navimipour and B. Zareie (2015) konten pembelajaran secara signifikan mempengaruhi kepuasan belajar karyawan [5] dan Hamid dkk, (2015) yang menemukan siswa lebih terlibat dengan konten kursus dan menunjukkan tingkat pemahaman dan penguasaan topik yang lebih tinggi dalam pembelajaran jarak jauh [23].

Perceived usefulness atau manfaat yang dirasakan, memuat kepercayaan bahwa menggunakan teknologi tertentu akan meningkatkan kinerja pendidikan atau pekerjaannya. Perceived usefulness berpengaruh terhadap kepuasan belajar jarak jauh. Hasil penujian SPSS ditemukan $P$ value adalah $0,000 \quad(<0,05)$ yang artinya hipotesis diterima. Manfaat yang dirasakan dalam pembelajaran jarak jauh pada masa pandemi antara lain dapat meningkatkan aktifitas kuliah, dapat meningkatkan kinerja, dapat meningkatkan produktifitas, dan mahasiswa merasakan pembelajaran online atau jarak jauh dapat berguna bagi karirnya nanti. Penelitian kami mendukung penelitian sebelumya yang dilakukan oleh Arbaugh (2000), bahwa pembelajaran jarak jauh dpat meningkatan efektifitas belajar, peningkatan kinerja, manfaat untuk masa depan, dan peningkatan produktifitas [27] dan Elkaseh (2016) media online dirasakan dapat memberi manfaat siswa di pendidikan tinggi Libya [6].

Interaktivitas didefinisikan sebagai kegiatan atau interaksi antar individu/siswa atau antar siswa dan instruktur. Learner-instructor interaction berpengaruh terhadap kepuasan belajar jarak jauh. Hasil penujian SPSS ditemukan $P$-value adalah $0,018(<0,05)$ yang artinya hipotesis diterima, tetapi Learner-learner interaction tidak berpengaruh terhadap kepuasan belajar jarak jauh $(P$-value $>0,05)$ yang artinya hipotesis ditolak. Selama pembelajaran jarak jauh pada masa pandemi gelombang pertama mahasiswa vokasi di Fakultas Tenik Universitas Negeri Surabaya banyak berinteraksi dengan dosen melalui media elektronik, tetapi mereka tidak banyak berinteraksi dengan sesama mahasiswa. Sehingga dalam penelitian ini hanya interaksi dengan dosen ditemukan berpengaruh terhadap kepuasan belajar jarak jauh. Penelitian kami mendukung penelitian sebelumnya yang dilakukan oleh Kuo (2014) yang menyatakan interaksi siswa dan instruktur merupakan salah satu prediktor yang baik bagi kepuasan belajar [29] dan Horzum (2015) menemukan interaktivitas adalah salah satu faktor yang mempengaruhi pembelajaran online [4].

\section{SIMPULAN DAN SARAN}

Penelitian ini bertujuan untuk menguji faktor-faktor yang diprediksi berpengaruh terhadap kepuasan belajar jarak jauh mahasiswa vokasi di masa pandemi COVID-19. Dari sembilan faktor yang diprediksi berpengaruh terhadap kepuasan belajar jarak jauh, hanya empat faktor terbukti secara signifikan berpengaruh terhadap kepuasan belajar yaitu sumber belajar elektronik yang baik (good eresourches), konten pembelajaran (learning content), manfaaat yang dirasakan (perceived usefulness) dan interaksi pembelajar dan dosen (learner-instructor interaction). Hasil peneletian ini dihasilkan teori dalam mengelola pembelajaran jarak jauh diperlukan pengelolaan sumber belajar elektronik dan konten pembelajaran dengan baik, manfaat dan interaksi dosen dan mahasiswa. Penelitian ini memberikan kontribusi terhadap pengelola pembelajaran dan dosen. Pengelola pendidikan dan dosen dapat memaksimalkan sumber belajar dan konten pembelajaran. Sumber belajar dan konten pembelajaran sangat bermanfaat dalam meningkatkan motivasi dan produktivitas mahasiswa karena mereka lebih banyak belajar secara mandiri di rumah. Mahasiswa merasakan manfaat pembelajaran jarak jauh menggunakan teknologi pada masa pandemi, sehingga diharapkan meskipun di masa pandemi COVID-19 ini, pembelajaran tetap dikelola secara baik. Interaksi antara mahasiswa dan dosen perlu dijaga dengan baik, mahasiswa merasa puas dengan pembelajaran jarak jauh, asalkan tetap ada perhatian dari dosen dengan memberikan umpan balik dengan segera, terhadap diskusi maupun pertanyaan dari mahasiswa. Penelitian ini memberikan kontribusi terhadap pengelola pembelajaran dan dosen.

Studi ini memiliki keterbatas dan saran sebagai berikut. Pertama, penelitian tidak bisa digeneralisasi untuk mahasiswa vokasi karena responden terbatas hanya pada mahasiswa di Universitas Negeri Surabaya. Responden mahasiswa vokasi dari Universitas yang lain perlu dilakukan untuk penelitian selanjutnya. Kedua, dalam penelitian ini ditemukan hanya empat faktor yang mempengaruhi kepuasan belajar mahasiswa. Hal ini diperkirakan karena waktu pengambilan data dilakukan pada awal masa pandemi, pada saat dosen, pengelola pembelajaran dan mahasiswa masih belum mempersiapkan pembelajaran jarak jauh dengan baik. sehingga perlu dilakukan penelitian lanjutan mulai tahun 2021 pada saat pembelajaran online atau jarak jauh sudah dipersiapkan lebih matang. 


\section{DAFTAR PUSTAKA}

[1] J. Bedford et al., "COVID-19: towards controlling of a pandemic," Lancet, vol. 395, no. 10229, pp. 1015-1018, 2020, doi: 10.1016/S0140-6736(20)30673-5.

[2] J. Traxler, "Distance learning-Predictions and possibilities," Educ. Sci., vol. 8, no. 1, 2018, doi: 10.3390/educsci8010035.

[3] C. G. Ogbonna, N. E. Ibezim, and C. A. Obi, "Synchronous versus asynchronous e-learning in teaching word processing: An experimental approach," South African J. Educ., vol. 39, no. 2, pp. 1-15, 2019, doi: 10.15700/saje.v39n2a1383.

[4] M. B. Horzum, "Interaction, structure, social presence, and satisfaction in online learning," Eurasia J. Math. Sci. Technol. Educ., vol. 11, no. 3, pp. 505-512, 2015, doi: 10.12973/eurasia.2014.1324a.

[5] N. Jafari Navimipour and B. Zareie, "A model for assessing the impact of e-learning systems on employees' satisfaction," Comput. Human Behav., vol. 53, pp. 475-485, 2015, doi: 10.1016/j.chb.2015.07.026.

[6] A. M. Elkaseh, K. W. Wong, and C. C. Fung, "Perceived Ease of Use and Perceived Usefulness of Social Media for e-Learning in Libyan Higher Education: A Structural Equation Modeling Analysis," Int. J. Inf. Educ. Technol., vol. 6, no. 3, pp. 192-199, 2016, doi: 10.7763/ijiet.2016.v6.683.

[7] M. Kurucay and F. A. Inan, "Examining the effects of learner-learner interactions on satisfaction and learning in an online undergraduate course," Comput. Educ., vol. 115, pp. 20-37, 2017, doi: 10.1016/j.compedu.2017.06.010.

[8] J. T. Nagy, "Evaluation of online video usage and learning satisfaction: An extension of the technology acceptance model," Int. Rev. Res. Open Distance Learn., vol. 19, no. 1, pp. 160185, 2018, doi: 10.19173/irrodl.v19i1.2886.

[9] L. Pham, Y. B. Limbu, T. K. Bui, H. T. Nguyen, and H. T. Pham, "Does e-learning service quality influence e-learning student satisfaction and loyalty? Evidence from Vietnam," Int. J. Educ. Technol. High. Educ., vol. 16, no. 1, 2019, doi: 10.1186/s41239-019-0136-3.

[10] A. M. Alemu and J. Cordier, "Factors influencing international student satisfaction in Korean universities," Int. J. Educ. Dev., vol. 57, no. November 2017, pp. 54-64, 2017, doi: 10.1016/j.jjedudev.2017.08.006.

[11] D. Kember, S. Ng, H. Tse, E. T. T. Wong, and M. Pomfret, "An Examination of the Interrelationships between Workload, Study Time, Learning Approaches and Academic Outcomes," Stud. High. Educ., vol. 21, no. 3, pp. 347-358, 1996, doi: $10.1080 / 03075079612331381261$.

[12] S. Çırak Kurt and I. Yıldırım, "The students' perceptions on blended learning: A Q method analysis," Kuram ve Uygulamada Egit. Bilim., vol. 18, no. 2, pp. 427-446, 2018, doi: 10.12738/estp.2018.2.0002.

[13] B. Z. Butt and K. U. Rehman, "A study examining the students satisfaction in higher education," Procedia - Soc. Behav. Sci., vol. 2, no. 2, pp. 5446-5450, 2010, doi: 10.1016/j.sbspro.2010.03.888.

[14] A. Sharma, M. Singh, R. Shukla, and S. Gupta, "Impact of E-resources among the Research Scholars of the Faculty of Social Science and the Department of Education of the University of Jammu, Jammu: A Case Study," Libr. Philos. Pract., vol. 2020, no. July, pp. 1-22, 2020.

[15] A. Arko-Cobbah, "The role of libraries in student-centred learning: The case of students from the disadvantaged communities in South Africa," Int. Inf. Libr. Rev., vol. 36, no. 3, pp. 263-271, 2004, doi: 10.1080/10572317.2004.10762643.

[16] K. H. Lau, T. Lam, B. H. Kam, M. Nkhoma, J. Richardson, and S. Thomas, "The role of textbook learning resources in e-learning: A taxonomic study," Comput. Educ., vol. 118, pp. 10-24, 2018, doi: 10.1016/j.compedu.2017.11.005.

[17] A. A. Askhamov, A. V. Konysheva, and A. R. Gapsalamov, "Use of E-resources of the learning environment in teaching mathematics to future engineers," Int. J. Environ. Sci. Educ., vol. 11, no. 5, pp. 673-684, 2016, doi: 10.12973/ijese.2016.340a.

[18] H. Y. Suhendi, M. A. Ramdhani, and F. S. Irwansyah, "Verification concept of assesment for physics education student learning outcome," Int. J. Eng. Technol., vol. 7, no. 3.21 Special Issue 21, pp. 321-325, 2018, doi: 10.14419/ijet.v7i2.29.13646.

[19] F. Nasser-Abu Alhija, "Teaching in higher education: Good teaching through students' lens," Stud. Educ. Eval., vol. 54, pp. 4-12, 2017, doi: 10.1016/j.stueduc.2016.10.006.

[20] S. Li, S. Yamaguchi, and J. I. Takada, "The influence of interactive learning materials on self- 
regulated learning and learning satisfaction of primary school teachers in Mongolia," Sustain., vol. 10, no. 4, pp. 1-19, 2018, doi: 10.3390/su10041093.

[21] J. Rajadurai, N. Alias, A. H. Jaaffar, and W. N. W. Hanafi, "Learners' Satisfaction and Academic Performance in Open and Distance Learning (ODL) Universities in Malaysia," Glob. Bus. Manag. Res., vol. 10, no. 3, p. 511, 2018.

[22] Y.-H. Lee, C. Hsiao, and S. Hadi, "Enhancing e-learning Acceptance: An Empirical Examination on individual and system characteristics," Acad. Manag. Proc., vol. 2012, no. 1, p. 15828, 2012, doi: 10.5465/ambpp.2012.15828abstract.

[23] S. Hamid, J. Waycott, S. Kurnia, and S. Chang, "Understanding students' perceptions of the benefits of online social networking use for teaching and learning," Internet High. Educ., vol. 26, pp. 1-9, 2015, doi: 10.1016/j.iheduc.2015.02.004.

[24] J. B. Arbaugh, "Managing the on-line classroom. A study of technological and behavioral characteristics of web-based MBA courses," J. High Technol. Manag. Res., vol. 13, no. 2, pp. 203-223, 2002, doi: 10.1016/S1047-8310(02)00049-4.

[25] P. C. Sun, R. J. Tsai, G. Finger, Y. Y. Chen, and D. Yeh, "What drives a successful eLearning? An empirical investigation of the critical factors influencing learner satisfaction," Comput. Educ., vol. 50, no. 4, pp. 1183-1202, 2008, doi: 10.1016/j.compedu.2006.11.007.

[26] T. Teo, "Modeling the determinants of pre-service teachers' perceived usefulness of elearning," Campus-Wide Inf. Syst., vol. 28, no. 2, pp. 124-140, 2011, doi: $10.1108 / 10650741111117824$

[27] J. B. Arbaugh, "Virtual Classroom Characteristics and Student Satisfaction with Internet-Based MBA Courses," J. Manag. Educ., vol. 24, no. 1, pp. 32-54, 2000, doi: 10.1177/105256290002400104.

[28] P. Ginns and R. A. Ellis, "Evaluating the quality of e-learning at the degree level in the student experience of blended learning," Br. J. Educ. Technol., vol. 40, no. 4, pp. 652-663, 2009, doi: 10.1111/j.1467-8535.2008.00861.x.

[29] Y. C. Kuo, A. E. Walker, K. E. E. Schroder, and B. R. Belland, "Interaction, Internet selfefficacy, and self-regulated learning as predictors of student satisfaction in online education courses," Internet High. Educ., vol. 20, pp. 35-50, 2014, doi: 10.1016/j.iheduc.2013.10.001.

[30] R. B. Ikhsan, L. A. Saraswati, B. G. Muchardie, Vional, and A. Susilo, "The determinants of students' perceived learning outcomes and satisfaction in BINUS online learning," Proc. 2019 5th Int. Conf. New Media Stud. CONMEDIA 2019, no. October 2017, pp. 68-73, 2019, doi: 10.1109/CONMEDIA46929.2019.8981813.

[31] N. Pellas, "The influence of computer self-efficacy, metacognitive self-regulation and selfesteem on student engagement in online learning programs: Evidence from the virtual world of Second Life," Comput. Human Behav., vol. 35, pp. 157-170, 2014, doi: 10.1016/j.chb.2014.02.048.

[32] J. Broadbent and W. L. Poon, "Self-regulated learning strategies \& academic achievement in online higher education learning environments: A systematic review," Internet High. Educ., vol. 27, no. September, pp. 1-13, 2015, doi: 10.1016/j.iheduc.2015.04.007.

[33] P. Ginns and R. Ellis, "Quality in blended learning: Exploring the relationships between on-line and face-to-face teaching and learning," Internet High. Educ., vol. 10, no. 1, pp. 53-64, 2007, doi: 10.1016/j.iheduc.2006.10.003.

[34] J. Varghese, M. Faith, and M. Jacob, "Impact of e-resources on learning in biochemistry: Firstyear medical students perceptions," BMC Med. Educ., vol. 12, no. 1, 2012, doi: 10.1186/14726920-12-21.

[35] R. A. S. Abuzaid, "Bridging the gap between the e-learning environment and e-resources: A case study in Saudi Arabia," Procedia - Soc. Behav. Sci., vol. 2, no. 2, pp. 1270-1275, 2010, doi: 10.1016/j.sbspro.2010.03.186. 